\title{
Fortification of Biscuit with Flaxseed: Biscuit Production and Quality Evaluation
}

\author{
${ }^{1}$ Lubna Masoodi, ${ }^{2}$ Dr Vidhu Aeri -Khalid Bashir \\ Department of Food Technology Faculty of Engineering and Interdisciplinary Sciences \\ Jamia Hamdard, Hamdard University, New Delhi-62
}

\begin{abstract}
Effects of fortification of flaxseed at different levels were assessed on the nutritional and sensory quality of biscuit. Supplementation of wheat flour with flaxseed powder was done at different levels $0-43 \%$. A novel fortified biscuit was successfully produced and it was observed as the concentration of flaxseed increased the moisture, fat, ash, protein showed gradual increase whereas dietary fibre showed a rapid increase and however, carbohydrate content was decreased. The antioxidant activity, phenolic concentration was linearly increased as the fortification was increased. Also the dark color intensity was increased with the increase in fortification. On the basis of nutritional and sensory quality, biscuit when fortified with blends of $10 \%$ flax seed resulted in better quality and nutritious biscuits (carbohydrate content $69.76 \%$, protein content $10.59 \%$, fat content $11.07 \%$, ash content $2.48 \%$ and fibre content $7.77 \%$ ).
\end{abstract}

Keywords: Biscuits, Wheat Flour, Flaxseed Powder.

\section{Introduction}

Biscuits represent a fast growing segment of food in India because of consumer demands for convenient and nutritious food products. The consumers demand has increased for the quality food products with taste, safety, convenience and nutrition. Thus nutrition has emerged as an added dimension in the chain of food product development (Ahmad, 1999; Shahzad et al., 2002). Biscuits are a popular foodstuff consumed by a wide range of population due to their varied taste, long shelf life and relatively low cost. Because of competition in the market and increased demand for healthy, natural and functional products, attempts are being made to improve the nutritive value of biscuits and functionality by modifyingtheir nutritive composition.Such effects are very often achieved by increasing the ratio of wholegra- in raw materials other than wheat or different types of dietary fibres in basic recipes with the attempt to increase biscuit's protein and mineral content for quality and availability (Tyagi et al., 2006) or increase dietary fibre content and improve prebiotic characteristics of the final product (Gallagher et al.,2003).

Okpala et al. (2011) studied the nutritional evaluation of biscuits produced from pigeon pea, cocoyam and sorghum flour blends. Ten different biscuit formulations were produced and same were evaluated for their proximate composition, antinutritional factors and protein quality. They concluded that biscuits showed promise in helping to combat protein malnutrition in those countries where protein malnutrition poses a threat. Ogunjobi et al. (2010) studied the physicochemical and sensory properties of cassava flour biscuits supplemented with cashew apple powder. The supplementation seemed to be suited for cassava flour substitution and it is possible to obtain biscuits of better quality.Sudha et al., 2007 reported, Influence of fibre from different cereals on the rheological characteristics of wheat flour dough and on biscuit quality. Demand for health oriented products such as sugar free, low calorie and high fibre products are increasing. One such recent trend is to increase the fibre content in food products to overcome health problems such as hypertension, diabetes and colon cancer, among others.

J. F. Carter 1993 studied the potential of flaxseed and flaxseed oil in baked goods and other products in human nutrition. Flax seed has a pleasant nutty flavor with few or no significant side effects. The principle effect of flaxseed in humans and animal nutrition are the high levels of alpha linolenic acid (ALA c18; 3 n-3) in its oil and the high fibre in the seed. The total flax plant is approximately $25 \%$ seed and $75 \%$ stem and leaves. The flaxseed is $35 \%$ oil, of which 55\% is ALA, a polyunsaturated, n-3 type fatty acid. Also the seed is $35 \%$ fibre, 28 to 30\% protein, and 6\% ash, or minerals. Joshua Lawrenz,Betty Herndon et al., 2002 studied, dietary flax oil reduces renal injury, oxidized LDL content, and tissue n-6/n-3 FA ratio in experimental polycystic kidney disease. ShahzadH. et al., 2006 studied Development and Evaluation of Nutritionally Superior Baked Products Containing Flaxseed. The unleavened flat breads were prepared from Whole Wheat Flour (WWF) fortified with 16\% Partially Defatted Flaxseed Flour (PDF) and 12\% full fat flaxseed flour (FFF).

Keeping in view the nutritive and health benefits of flaxseed, the present investigation was aimed to improve the nutritional, health and sensory properties of biscuit. 


\section{Materials And Methods}

The raw materials wheat flour (Triticum Aestivum), flaxseed (Linumusitatissimum) were obtained from the local market.

Flaxseed was roasted in an oven (Kheera instruments) at $90^{\circ} \mathrm{C}$ for $10 \mathrm{~min}$ prior to grinding and then sieved thrice through 10 mesh. Grinding was done inUshaGinder.

Sample PreparationFour samples of the biscuit were prepared using sample one as control containing only wheat flour, while the second sample contained wheat flour $89 \%$ and flaxseed powder $11 \%$, sample three contained wheat flour $75 \%$ and flaxseed powder $25 \%$ and the fourth sample contained $57 \%$ wheat flour and $43 \%$ flaxseed powder. Besides this all the samples were blended with $42 \mathrm{~g}$ paste. Paste was made from $504 \mathrm{~g}$ of sugar, $25 \mathrm{~g}$ of milk powder, $252 \mathrm{~g}$ of refined oil and $8.4 \mathrm{~g}$ of sodium bicarbonate.

Chemical characteristics Moisture, ash and fat content were determined according to AOAC 2000 methods. Protein content was determined as per (IS: 7219:1973): Kjeldhal Method, protein content was obtained by using the conversion factor of 6.25, Dietary fibre was determined by (IS: 11062) and carbohydrate content by difference method.

Biscuit Preparation Wheat flour and flaxseed powder blends were prepared in the ratio of 50:0, 45:5, 40:10 and 35:15 respectively. All the blends were passed through 10 mesh sieve thrice for efficient mixing. Paste was then added to all samples in the same proportion (42g). Paste was added to the mixture of flour in dough mixer. Then water was added to the different samples in the same proportion $(8 \mathrm{ml}$ in each). The water used was RO purified. Kneading was done for $178 \mathrm{rpm}$ for $3 \mathrm{~min}$ in each case. The dough mixer contained shafts that rotate in opposition to pull the dough simultaneously in two different directions, which minim minimizes the amount of balling that can occur. The dough was then sheeted to $3.5 \mathrm{~mm}$ thickness and then moulded by biscuit moulder into $45 \mathrm{~mm}$ thickness and thenbaked in a bakery oven at $200^{\circ} \mathrm{C}$ for $10 \mathrm{~min}$. The biscuit samples were then cooled for $30 \mathrm{~min}$ and packed in LDPE for chemical and sensory analysis.

Sensory evaluation Biscuits were evaluated for overall acceptability (colour, texture, aroma and taste) and was carried out as per 9 point Hedonic scale, by the help of ten semi trained judges.

Statistical analysis ANOVA - post hoc comparison- ns. The means were compared using Duncan's multiple range tests (2007).

\section{Results And Discussion}

Proximate composition of raw materialsFlaxseed powder had highest fat, protein, dietary fibre and ash content, while aswheat flour contained higher carbohydrate content.Table 1.

Proximate composition of biscuit samples Fortification of biscuit resulted in increased protein, fat, ash and dietary fibre content, while as carbohydrate content was decreased, as compared to control. The fat, protein and dietary fibre were increased at higher rate because of the flaxseed. The fat content was also increased because of the paste added. The fibre content was decreased as the fortification was increased because flaxseed contain moderate amount of carbohydrate, Table 2. The results agreed with other research workers, Vitali et al. (2008), Okpala et al. (2011), Tyagi et al. (2006), who reported the incorporation of plant proteins, soy flour, inulin, pigeon pea, sorghum, mustard flour increased the protein content, fibre content, moisture content and ash content of the final products.

Sensory Characteristics of biscuits The Sensory evaluation was carried out as per 9 point Hedonic scale, Table 3. The sensory attributes that were taken into consideration include: color, texture, aroma, taste, overall acceptability and rank. The values are the means of ten readings. Among the three fortified samples, the second sample had highest overall acceptability, compared to the control.

\section{Tables}

Table 1: Proximate composition of raw materials.

\begin{tabular}{ccccccc}
\hline S. No. & $\begin{array}{c}\text { Moisture, } \\
\%\end{array}$ & Ash, \% & Fat, \% & Protein, \% & $\begin{array}{c}\text { Dietary } \\
\text { fibre, } \%\end{array}$ & $\begin{array}{c}\text { Carbohydrate, } \\
\%\end{array}$ \\
\hline Wheat & $12.31 \pm$ & $0.85 \pm$ & $1.02 \pm 0.01$ & $9.00 \pm 0.08$ & $2.76 \pm$ & $76.73 \pm 0.11$ \\
flour & 0.15 & 0.03 & & & 0.12 & \\
Flaxseed & $8.66 \pm$ & $3.59 \pm 0.21$ & $41.63 \pm 0.34$ & $16.07 \pm 0.29$ & $9.97 \pm 0.05$ & $30.13 \pm 0.16$ \\
& 0.08 & & & & & \\
\hline
\end{tabular}

${ }^{\mathrm{a}}$ Mean Value \pm standard deviation.

Table 2: Proximate composition ${ }^{\mathrm{a}, \mathrm{b}}$ of biscuit samples.

\begin{tabular}{ccccccc}
\hline S. No. & $\begin{array}{c}\text { Moisture, } \\
\%\end{array}$ & Ash, \% & Fat, \% & Protein, \% & $\begin{array}{c}\text { Dietary } \\
\text { fibre, } \%\end{array}$ & $\begin{array}{c}\text { Carbohydrate, } \\
\%\end{array}$ \\
\hline Control & $5.97 \pm 0.29^{\mathrm{a}}$ & $0.83 \pm 0.02^{\mathrm{a}}$ & $4.04 \pm 0.02^{\mathrm{a}}$ & $8.74 \pm 0.27^{\mathrm{a}}$ & $1.67 \pm 0.04^{\mathrm{d}}$ & $80.22 \pm 0.68^{\mathrm{a}}$ \\
\hline
\end{tabular}




\begin{tabular}{ccccccc}
\hline 01 & $6.07 \pm 0.41^{\mathrm{a}}$ & $1.84 \pm 0.01^{\mathrm{b}}$ & $10.16 \pm$ & $9.09 \pm 0.08^{\mathrm{b}}$ & $7.16 \pm 0.02^{\mathrm{c}}$ & $72.34 \pm 0.53^{\mathrm{b}}$ \\
& & & $0.01^{\mathrm{b}}$ & & & \\
02 & $6.30 \pm 0.24^{\mathrm{a}}$ & $2.49 \pm 0.10^{\mathrm{c}}$ & $11.08 \pm$ & $10.53 \pm$ & $7.77 \pm 0.07^{\mathrm{b}}$ & $69.7 \pm 0.12^{\mathrm{c}}$ \\
& & & $0.09^{\mathrm{c}}$ & $0.04^{\mathrm{c}}$ & & \\
03 & $6.63 \pm 0.29^{\mathrm{a}}$ & $2.64 \pm 0.20^{\mathrm{c}}$ & $\begin{array}{c}11.55 \pm \\
0.02^{\mathrm{d}}\end{array}$ & $\begin{array}{c}10.84 \pm \\
0.03^{\mathrm{c}}\end{array}$ & $8.09 \pm 0.04^{\mathrm{a}}$ & $68.38 \pm 0.11^{\mathrm{d}}$ \\
\hline
\end{tabular}

${ }^{\mathrm{a}}$ Mean values \pm standard deviation $(\mathrm{n}=10)$.

${ }^{\mathrm{b}}$ Mean values marked with different superscripts in the same column are significantly different- Duncan ( $\mathrm{p} \leq$ $0.05)$.

Table 3: Sensory Characteristics ${ }^{\mathrm{a}, \mathrm{b}}$ of biscuit samples.

\begin{tabular}{ccccccc}
\hline S. No. & Color & Texture & Aroma & Taste & $\begin{array}{c}\text { Overall } \\
\text { acceptability }\end{array}$ & Rank \\
\hline Control & $8.20 \pm 0.60^{\mathrm{b}}$ & $8.10 \pm 0.54^{\mathrm{a}}$ & $7.9 \pm 0.54^{\mathrm{b}}$ & $7.8 \pm 0.75^{\mathrm{a}}$ & $7.7 \pm 0.78^{\mathrm{a}}$ & $7.8 \pm 0.75^{\mathrm{ab}}$ \\
01 & $8.00 \pm$ & $7.80 \pm 0.60^{\mathrm{a}}$ & $7.00 \pm 0.89^{\mathrm{a}}$ & $7.9 \pm 0.70^{\mathrm{a}}$ & $7.7 \pm 0.78^{\mathrm{a}}$ & $7.7 \pm 0.78^{\mathrm{ab}}$ \\
02 & $0.63^{\mathrm{ab}}$ & & & & & \\
03 & $7.10 \pm 0.54^{\mathrm{b}}$ & $7.8 \pm 0.60^{\mathrm{a}}$ & $8.10 \pm 0.54^{\mathrm{b}}$ & $8.10 \pm 0.30^{\mathrm{a}}$ & $7.8 \pm 0.60^{\mathrm{a}}$ & $8.00 \pm 0.45^{\mathrm{b}}$ \\
$0.80 \pm 00^{\mathrm{a}}$ & $7.70 \pm 0.46^{\mathrm{a}}$ & $7.00 \pm 0.89^{\mathrm{a}}$ & $7.70 \pm 0.64^{\mathrm{a}}$ & $7.50 \pm 0.67^{\mathrm{a}}$ & $7.30 \pm 0.64^{\mathrm{a}}$ \\
\hline
\end{tabular}

${ }^{a}$ Mean values \pm standard deviation $(\mathrm{n}=10)$.

${ }^{\mathrm{b}}$ Mean values marked with different superscripts in the same column are significantly different- Duncan ( $\mathrm{p} \leq$ $0.05)$.

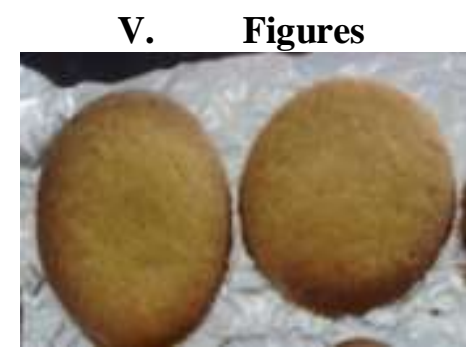

Fig. 1: Control Biscuit sample

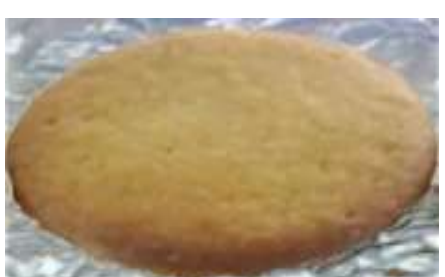

Fig. 2: Fortified Biscuit sample 1

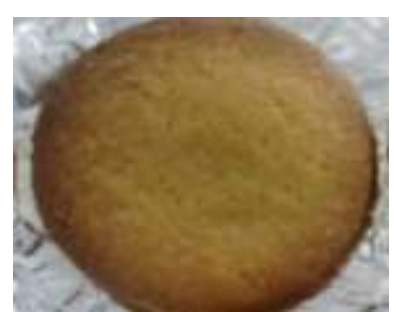

Fig. 3: Fortified Biscuit sample 2

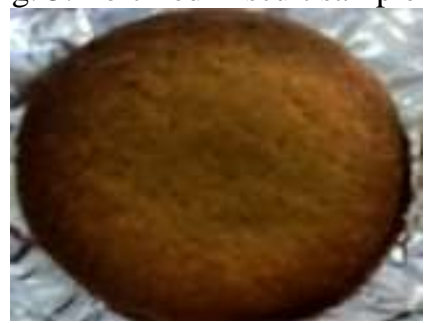

Fig. 4: Fortified Biscuit sample 3 


\section{Conclusion}

A novel biscuit product, fortified with flax seed was successfully produced. Flax seed increased the protein, ash, fat, fibre and dark color of the biscuit, when compared to the control (reference biscuit). The moisture was slightly increased in the fortified samples. The color of the fortified samples attained more dark color as the fortification was increased. However, the texture was slightly decreased with fortification but described no undesirable change. On the basis of nutritional and sensory quality, biscuit when fortified with blends of $10 \%$ flax seed resulted in better quality and nutritious biscuits (carbohydrate content $69.76 \%$, protein content $10.59 \%$, fat content $11.07 \%$, ash content $2.48 \%$ and fibre content $7.77 \%$ ).

\section{References}

[1] 2000 AOAC (2000) (Association of Official Analytical Chemists), Approved methods of the AOAC, William Horwitz.

[2] AACC (2000) Approved laboratory methods, American Association of Cereal Chemists, Minnesota,USA

[3] Ahmad AOCS press, Champaign, Washington. Calder, P.C., 1999. Dietary fatty acids and the immune system. Nutr. Rev., 56: S70-S83.

[4] Akobundu ENT, Ubbaonu CN, Ndupuh CE (1998). Studies on the baking potential of non-wheat composite flours. J. Food Sci. Technol. (25): 211-214.

[5] Carter, J.F 1993, Potential of flaxseed and flaxseed oil in baked goods and other products in human nutrition, Cereal Foods World, 38, 10, pp. 753-759.

[6] Echendu CA, Onimawo IA, Somtochi A (2004). Production and Evaluation of Doughnuts and Biscuits from Maize- Pigeon pea Flour Blends. Nig. Food J. (22): 147-153

[7] Gallagher, P.R. Flatt, G. Duffy, Y.H.A. Abdel-Wahab, 2003 The effects of traditional antidiabetic plants on in vitroglucose diffusion, Nutrition Research 23 (2003) 413-424

[8] Iqbal MA.. Quality aspects of biscuits containing figs in their formulation. M.Sc Thesis Dept Food Techol. UnivAgric Faisalabad. 1997

[9] Joshua Lawrenz, Betty Herndon Dietary Flaxseed Oil Protects against Bleomycin-Induced Pulmonary Fibrosis in Rats, Pulmonary Medicine, Volume 2012 (2012), Article ID 457031

[10] L. C. Okpala and E. C. Okoli , 2001 Nutritional evaluation of cookies produced from pigeon pea, cocoyam and sorghum flour blends, African Journal of Biotechnology Vol. 10(3), pp. 433-438.

[11] Larmond E. Laboratiry methods of sensory evaluation of food, Research branch Canada. Deptagric Publications. 1980.

[12] Milner M (1974). Protein-fortified cereal foods for developing countries, Cereal Sci. Today, 19: 509

[13] Ogunjobi and S.O. Ogunwolu, 2010 Physicochemical and Sensory Properties of Cassava Flour Biscuits Suplemented with Cashew Apple Powder, Journal of Food Technology,Volume: 8, Issue: 1, Page No.: 24-29

[14] Shahzad HUSSAIN, Faqir Muhammad Anjum, 2006 Physical and Sensoric Attributes of Flaxseed Flour Supplemented Cookies, Turk J Biol, 30 (2006) 87-92.

[15] Shahzad Hussain1, Faqir Muhammad Anjum, MasoodSadiq Butt, Mohammad SalehAlamri, 2012 Development and Evaluation of Nutritionally Superior Baked Products Containing Flaxseed, Pakistan Journal of Nutrition 11 (2): 160-165

[16] Shearer AEH. Physicochemical properties of muffins prepared with various levels of flaxseed flour. Animal and Food Sciences Univ Delaware College of Agric Newark. 2002.

[17] Steel RGD, Torrie JH. and Dickey D. Principles and Procedures of Statistics. A biometrical approach. 3rd ed. McGraw Hills Book Co. Inc New York. 1997.

[18] Sudha, M.L., Vetrimani, R. and Leelavathi, K. 2007. Influence of fibre from different cereals on the rheological characteristics of wheat flour dough and on biscuit quality. Food Chemistry 100: 1365-1370.

[19] TsenCC.. Regular and protein fortified biscuits from the composite flours. Cereal Foods World (21): 633-40. 1976

[20] Tyagi, M.R. Manikantan, Harinder Singh Oberoi, 2006 Effect of mustard flour incorporation on nutritional, textural and organoleptic characteristics of biscuit, Journal of Food Engineering, Volume 80, Issue 4, June 2007, Pages $1043-1050$.

First Author: Lubna Masoodi

Authors

M. Tech. Food Technology

Faculty of Engineering and Interdisciplinary Sciences

Jamia Hamdard, Hamdard University-62

Second Author: Dr Vidhu Aeri

Associate Professor

Faculty of Phytochemistry and Pharmacognosy

Jamia Hamdard, Hamdard University-62

Third Author: Khalid Bashir

Department of Food Technology

Faculty of Engineering and Interdisciplinary Sciences

Jamia Hamdard, Hamdard University-62 